\title{
Restoring the Sagebrush Component in Crested Wheatgrass-Dominated Communities
}

\author{
Kirk W. Davies, ${ }^{1}$ Chad S. Boyd, ${ }^{1}$ and Aleta M. Nafus ${ }^{2}$ \\ Authors are ${ }^{1}$ Rangeland Scientists, USDA-ARS, Burns, OR 97720 USA; and ${ }^{2}$ Research Associate, Oregon State University, Burns, OR 97720 USA
}

\begin{abstract}
Monotypic stands of crested wheatgrass (Agropyron cristatum [L] Gaertm. and Agropyron desertorum [Fisch.] Schult.), an introduced grass, occupy vast expanses of the sagebrush steppe. Efforts to improve habitat for sagebrush-associated wildlife by establishing a diverse community of native vegetation in crested wheatgrass stands have largely failed. Instead of concentrating on a diversity of species, we evaluated the potential to restore the foundation species, Wyoming big sagebrush (Artemisia tridentata spp. wyomingensis [Beetle \& A. Young] S. L. Welsh), to these communities. We investigated the establishment of Wyoming big sagebrush into six crested wheatgrass stands (sites) by broadcast seeding and planting seedling sagebrush across varying levels of crested wheatgrass control with glyphosate. Planted sagebrush seedlings survived at high rates $(\sim 70 \%$ planted sagebrush survival $3 \mathrm{yr}$ postplanting), even without crested wheatgrass control. However, most attempts to establish sagebrush by broadcast seeding failed. Only at high levels of crested wheatgrass control did a few sagebrush plants establish from broadcasted seed. Sagebrush density and cover were greater with planting seedlings than broadcast seeding. Sagebrush cover, height, and canopy area were greater at higher levels of crested wheatgrass control. High levels of crested wheatgrass control also created an opportunity for exotic annuals to increase. Crested wheatgrass rapidly recovered after glyphosate control treatments, which suggests multiple treatments may be needed to effectively control crested wheatgrass. Our results suggest that planting sagebrush seedlings can structurally diversify monotypic crested wheatgrass stands to provide habitat for sagebrushassociated wildlife. Though this is not the full diversity of native functional groups representative of the sagebrush steppe, it is a substantial improvement over other efforts that have largely failed to alter these plant communities. We also hypothesize that planting sagebrush seedlings in patches or strips may provide a relatively inexpensive method to facilitate sagebrush recovery across vast landscapes where sagebrush has been lost.
\end{abstract}

Key Words: Agropyron cristatum, Artemisia tridentata, establishment, restoration, seedings

\section{INTRODUCTION}

Crested wheatgrass (Agropyron cristatum [L.] Gaertm. and Agropyron desertorum [Fisch.] Schult.) is a nonnative perennial bunchgrass that has been seeded on 6-11 million ha in western North America (Maryland et al. 1992; Lesica and Deluca 1996; Henderson and Naeth 2005; Vaness and Wilson 2008). It was initially seeded in sagebrush (Artemisia) plant communities to increase livestock forage and to displace halogeton (Halogeton glomeratus [M. Bieb.] C. A. Mey), a plant poisonous to sheep (Miller 1956; Frischknecht 1968). Recently, crested wheatgrass has been seeded after wildfires because it suppresses undesirable exotic annual grasses (Arredondo et al. 1998; Davies et al. 2010), decreases runoff risk, establishes well, and increases livestock forage (Pellant and Lysne 2005; Romo 2005; Waldron et al. 2005; Hansen and Wilson 2006). In the sagebrush biome, particularly in plant communities dominated by Wyoming big sagebrush (Artemisia tridentata spp. wyomingensis [Beetle \& A. Young] S. L. Welsh), practitioners have often elected to seed crested wheatgrass over native bunchgrasses after disturbances because it is less expensive, more available, and establishes better than native bunchgrasses (Robertson et al. 1966; Hull 1974; Asay et al. 2001; Epanchin-Niell et al. 2009; Boyd and Davies 2010, 2012).

Correspondence: Kirk W. Davies, 67826-A Hwy 205, Burns, OR 97720, USA. Email: kirk.davies@oregonstate.edu

Manuscript received 2 October 2012; manuscript accepted 5 March 2013.

(c) 2013 The Society for Range Management
Crested wheatgrass has also been suggested as a bridge species to convert exotic annual-invaded rangelands to native perennial-dominated plant communities with crested wheatgrass functioning as a place holder for native perennial species (Cox and Anderson 2004). However, crested wheatgrass often forms monotypic stands because it is highly competitive with native bunchgrasses (Hull and Klomp 1967; Asay et al. 2001), dominates the seedbank, and limits the growth and recruitment of native plants (Marlette and Anderson 1986; Hendersen and Naeth 2005; Gunnell et al. 2010). Thus, efforts to significantly increase native plant densities in crested wheatgrass stands have largely failed in the sagebrush steppe because crested wheatgrass rapidly recovers from control treatments (e.g., Hulet et al. 2010; Fansler and Mangold 2011). Multiple-year control of crested wheatgrass is probably needed to open the stands for recruitment of native species; however, exotic annuals may pose a significant risk if crested wheatgrass is effectively controlled and native perennials are slow to establish or do not establish (Hulet et al. 2010).

Efforts to restore crested wheatgrass-dominated rangelands to their full complement of native plant species or even native plant functional groups have a high probability of failure. Therefore, it may be more opportune to focus on reestablishing foundation species, species that have disproportionate control over resources in plant communities. Big sagebrush is considered a foundation species (Prevey et al. 2010) that would be important to reestablish in crested wheatgrass stands to mitigate the widespread loss of habitat for sage grouse and other sagebrush obligate wildlife species (Knick et al. 2003; Schroeder et al. 2004; Davies et al. 2011b). Converting 
monocultures of crested wheatgrass to sagebrush-crested wheatgrass communities would increase habitat for sagebrush obligate and facultative wildlife (McAdoo et al. 1989; Kennedy et al. 2009). Addition of sagebrush to crested wheatgrass stands would diversify the structure and function of these introduced grasslands. Crested wheatgrass negatively affects sagebrush seedling survival, but once established, sagebrush plants are likely to persist because of high niche differentiation (Gunnell et al. 2010). Thus, there is a need to investigate establishing sagebrush in crested wheatgrass stands.

The objective of this study was to investigate the establishment of Wyoming big sagebrush from broadcast seeding and planting seedlings in monotypic crested wheatgrass stands. Because crested wheatgrass is an effective competitor (Marlette and Anderson 1986; Henderson and Naeth 2005; Gunnell et al. 2010), we will also evaluate the effect of differing levels of crested wheatgrass control on sagebrush establishment and growth. We expected sagebrush density and cover to be greater with higher levels of crested wheatgrass control and where seedlings were used instead of seed. We also expected that greater crested wheatgrass control will produce taller sagebrush with larger canopy areas.

\section{METHODS}

\section{Study Area}

The study sites were located approximately $75 \mathrm{~km}$ south of Burns, Oregon, USA, on the Malheur National Wildlife Refuge (lat $42^{\circ} 57^{\prime} 40 \mathrm{~N}$, long $118^{\circ} 49^{\prime} 30 \mathrm{~W}$ ). Study sites ranged in elevation from $1275 \mathrm{~m}$ to $1300 \mathrm{~m}$, and mean annual precipitation was 280-300 $\mathrm{mm}$. Crop year precipitation (October 1-September 30) was 99\%, 100\%, 150\%, and $78 \%$ of the long-term average in 2009, 2010, 2011, and 2012 at the Burns Weather Service Office Airport, OR (Western Regional Climate Center 2012). Slopes varied from $0 \%$ to $5 \%$ and aspect varied from south to east at the study sites. Climate is typical of the northern Great Basin with hot, dry summers and cool, wet winters. Soils were Xeric Haplodurids and Xeric Aridurids. The study area was drill seeded with crested wheatgrass in 1981 after a wildfire. In 2009 , prior to treatments to control crested wheatgrass the study sites were near-monocultures of crested wheatgrass with no sagebrush reestablishment. Based on site characteristics, potential natural vegetation could have largely consisted of Wyoming big sagebrush, bluebunch wheatgrass (Psuedoregneria spicata [Pursh] A. Löve), Thurber needlegrass (Achnatherum therberianum [Piper] Barkworth), Sandberg bluegrass (Poa secunda J. Presl), and bottlebrush squirreltail (Elymus elymoides [Raf.] Swezey). Study sites had not been grazed by livestock for the past $10+$ yr. Wildlife had unrestricted access to the study sites.

\section{Experimental Design and Measurements}

We used a randomized complete block design with six blocks to evaluate establishing sagebrush in crested wheatgrass stands. Blocks were used to account for differences in site characteristics (soils, slope, and aspect). Site characteristics were uniform within blocks. Blocks were 0.5 to $1 \mathrm{~km}$ from each other. Each block consisted of eight $3 \times 6 \mathrm{~m}$ treatment plots with $0.5 \mathrm{~m}$ buffers between plots. Treatments were randomly assigned to plots within block. Treatments were the factorial combination of four different rates of glyphosate and two different sagebrush establishment methods. Glyphosate, as Pronto Big $\mathrm{N}^{\prime}$ Tuf mixed 50:50 with water, was brushed on $0 \%, 25 \%$, $50 \%$, or $75 \%$ of the crested wheatgrass plants (based on density) in treatment plots in late April and early June. Sagebrush establishment was attempted by reintroducing sagebrush as broadcast (by hand) seed at 1000 pure live seed per $\mathrm{m}^{2}$ or as seedlings at one seedling per $\mathrm{m}^{2}$ in treatment plots in September 2009. Sagebrush seedlings were grown by planting five sagebrush seeds in seedling cone containers in a three-season greenhouse in May 2009. Cone containers were $3.8 \mathrm{~cm}$ diameter at the top and $21 \mathrm{~cm}$ tall. Sagebrush seedlings were thinned to one individual per cone container. At the time of planting, sagebrush seedlings varied in height from $10 \mathrm{~cm}$ to $15 \mathrm{~cm}$. Sagebrush seedlings were planted by digging a hole approximately $21 \mathrm{~cm}$ deep, placing the seedling in the hole, and pressing the soil around the roots of the seedlings.

Herbaceous vegetation cover and density were measured along two, 6-m transects in each treatment plot in June 2010, 2011, and 2012. Transects were spaced $1 \mathrm{~m}$ from treatment edge and each other. On each transect, five $0.2-\mathrm{m}^{2}$ frames were spaced at 1-m intervals. Herbaceous cover by species, litter, and bare ground were visually estimated in the $0.2-\mathrm{m}^{2}$ frames. Herbaceous density by species was also measured in the $0.2 \mathrm{~m}^{2}$ frames. Sagebrush density was measured in June 2010, 2011, and 2012 by dividing the treatment plot into thirds, each third being $1 \times 6 \mathrm{~m}$, and counting all sagebrush rooted inside the $1 \times$ $6 \mathrm{~m}$ subplots. Sagebrush heights and canopy area were also determined by measuring all sagebrush plants in each plot in July 2012. Sagebrush height was measured from the ground to the highest point of the sagebrush plant (excluding reproductive stems). Canopy area was determined by measuring the longest diameter of the sagebrush canopy and then the diameter perpendicular to the center of the first diameter. Canopy area was then calculated as elliptical area using the two measured diameters of the sagebrush canopy. Sagebrush cover was then calculated by summing all the sagebrush canopy areas from the plot, dividing by the total area of the plot, and multiplying by 100.

\section{Statistical Analyses}

We used repeated measures analysis of variance (ANOVA) using the mixed models procedure (Proc Mix) in SAS v. 9.2 (SAS Institute, Cary, NC) to determine the influence of different levels of crested wheatgrass control and establishment method (seeds or seedlings) on response variables that were repeatedly sampled. Fixed variables were treatments, year, and their interactions. Site and site by treatment interactions were considered random effects. Covariance structure was determined using Akaike's Information Criterion (Littell et al. 1996). Nonrepeated variables were analyzed with a mixed model ANOVA. Treatments and their interactions were considered fixed effects, while site and site by treatment interactions were considered random effects. Sagebrush height and canopy area were compared only among the different control levels for areas planted with sagebrush seedlings 


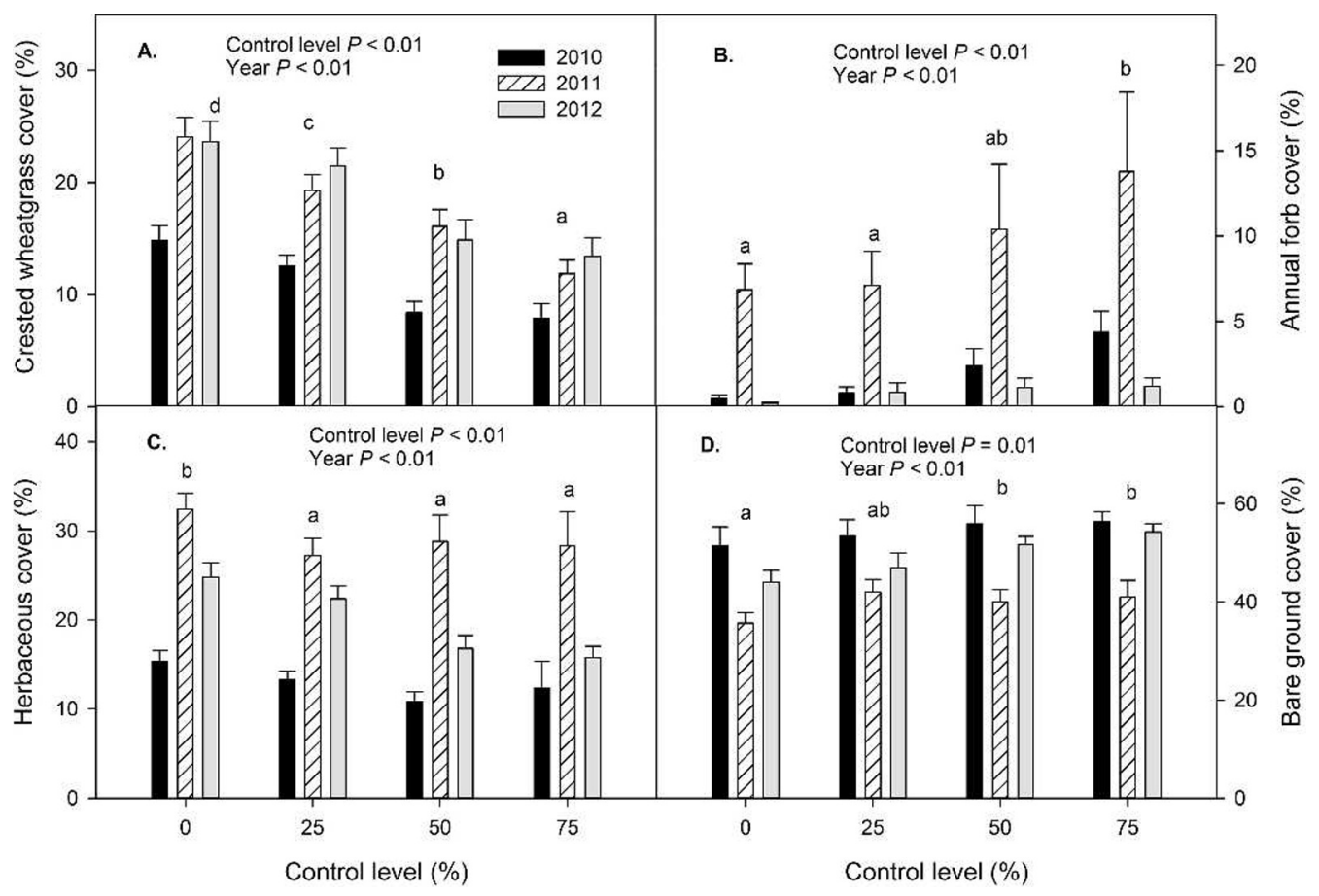

Figure 1. Crested wheatgrass (A), annual forb (B), total herbaceous (C), and bare ground (D) cover in 2010, 2011, and 2012 across varying levels of crested control with glyphosate. Data from seedling and seeded plots are averaged together in figures. Lower case letters indicate response variable differences $(P \leq 0.05)$ among control levels.

because most seeded plots did not have any sagebrush establishment. Tukey's Honestly Significant difference was used to separate means. Significance level for all tests was set at $P \leq 0.05$. Response variable means were reported with standard errors. For analyses, herbaceous cover and density were separated into seven groups: Sandberg bluegrass, large native perennial bunchgrass, crested wheatgrass, crested wheatgrass seedlings, exotic annual grasses (cheatgrass was the only annual grass detected), perennial forbs, and annual forbs. The annual forb group largely consisted of the exotic annual desert matwort (Alyssum desertorum Stapf).

\section{RESULTS}

\section{Herbaceous, Bare Ground, and Litter Cover}

In general, higher control levels decreased crested wheatgrass cover $(P<0.01$; Fig. $1 \mathrm{~A})$, whereas crested wheatgrass seedling cover increased $(P<0.01)$. Averaged across all three posttreatment years, crested wheatgrass cover in the $0 \%$ control (no glyphosate) was approximately double that of the cover in the $75 \%$ control level plots. Crested wheatgrass seedling cover average across all posttreatment years was $0.24 \pm 0.07$, $0.19 \pm 0.07,0.51 \pm 0.13$, and $0.41 \pm 0.10 \%$ in the $0 \%, 25 \%$, $50 \%$, and $75 \%$ control levels, respectively. The two lower control levels were different from the higher control levels $(P<0.01)$. The lower control levels did not differ from each other nor did the higher control levels $(P>0.05)$. Treatment used to establish sagebrush did not influence crested wheatgrass or crested wheatgrass seedling cover $(P=0.71$ and 0.65 , respectively). Sandberg bluegrass, native bunchgrass, annual grass, and perennial forb cover did not vary by control level or reestablishment method $(P>0.05)$. Annual forb cover generally increased at higher control levels and varied by year (Fig. $1 \mathrm{~B} ; P<0.01)$. Annual forb cover was 2.5 -fold greater in the highest control level compared to the no control level averaged across all posttreatment years. Reestablishment method did not influence annual forb cover $(P=0.11)$. Total herbaceous cover was generally greatest at the lowest control levels, and bare ground was greatest at the highest control rates $(P<0.01$; Fig. $1 \mathrm{C}$ and $1 \mathrm{D}$, respectively). Total herbaceous cover and bare ground did not vary by reestablishment method $(P=0.89$ and 0.76 , respectively). Litter cover did not vary by control rate or reestablishment method ( $P=0.69$ and 0.81 , respectively). Interactions between control level and establishment method and between year and control level or establishment method were not significant for any measured response variables cover $(P>0.05)$.

\section{Herbaceous Density}

Crested wheatgrass density generally decreased with higher rates of control (Fig. 2A; $P<0.01$ ). Crested wheatgrass density also varied by year (Fig. $2 \mathrm{~A} ; P<0.01$ ), but did not differ between establishment methods $(P=0.37)$. Averaged across all posttreatment years, the $0 \%$ control plots had between 1.7 and 3.1 crested wheatgrass plants $\cdot \mathrm{m}^{-2}$ more than the plots receiving some level of crested wheatgrass control. Crested wheatgrass seedling density varied by year $(P<0.01)$ but did not differ by control level or establishment method $(P=0.37$ and 0.77 , respectively). Sandberg bluegrass and native perennial grass density did not vary by control level or establishment method $(P>0.05)$. The study sites had very little to no Sandberg bluegrass and native perennial grasses. Average density for Sandberg bluegrass and native perennial grasses 


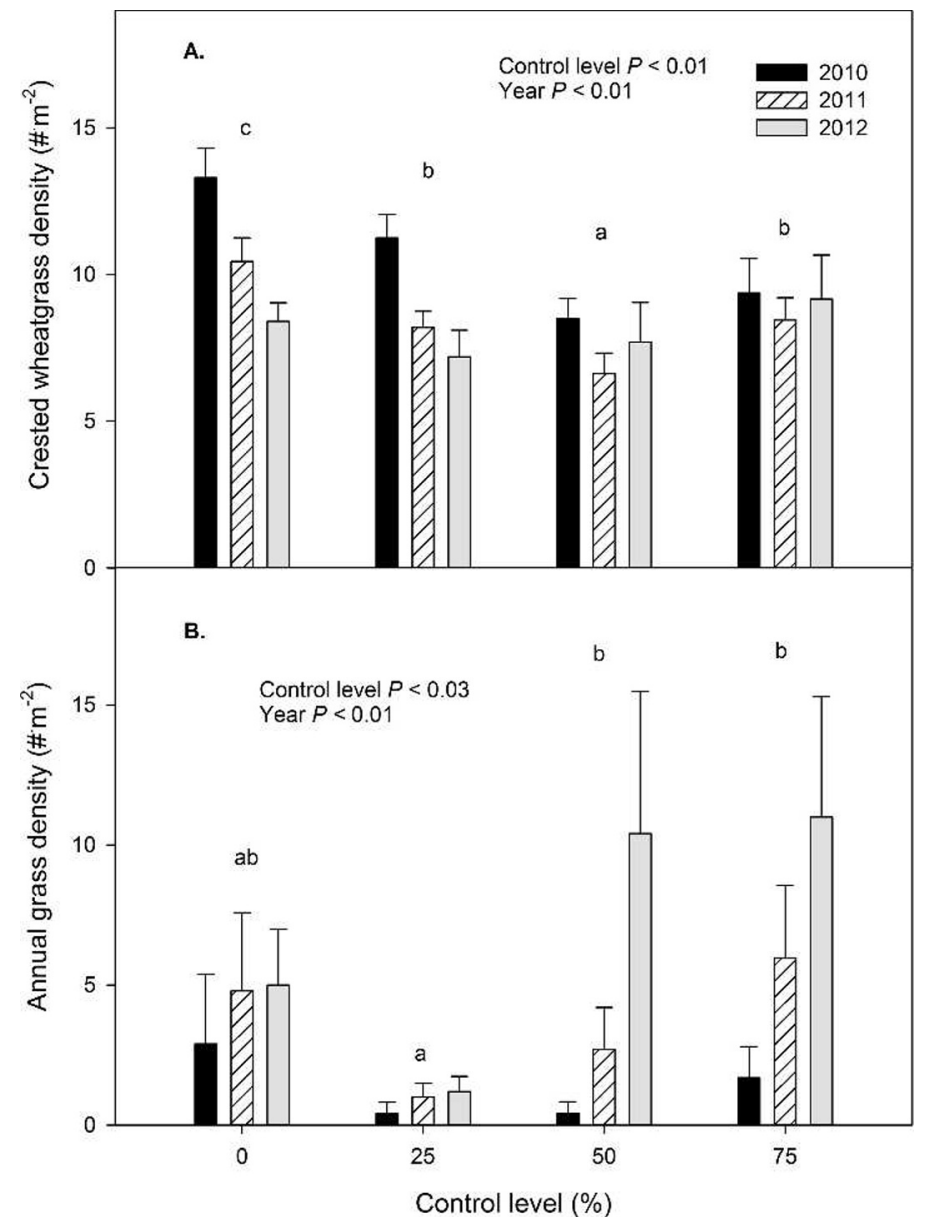

Figure 2. Crested wheatgrass (A) and annual grass (B) density in 2010, 2011, and 2012 across varying control levels of crested wheatgrass with glyphosate. Data from seedling and seeded plots are averaged together in figures. Lower case letters indicate response variable differences $(P \leq 0.05)$ among control levels.

was $0.02 \pm 0.01$ and $<0.01 \pm<0.01$ plants $\cdot \mathrm{m}^{-2}$, respectively. Annual grass density varied by control level and year (Fig. 2B; $P=0.03$ and $<0.01$, respectively), but not by establishment method $(P=0.73)$. The $25 \%$ control level differed from the other control levels $(P<0.05)$, except it was not different from the no control $(P=0.07)$. Annual grass density did not vary among the other control levels $(P>0.05)$. Perennial forb and annual forb density did not vary by control level or establishment method $(P>0.05)$. Perennial forbs were very uncommon across the study sites with an average density of $0.06 \pm 0.04$ plants $\cdot \mathrm{m}^{-2}$. Interactions between control level and establishment method and between year and control level or establishment method did not significantly influence the density of any measured response variable $(P>0.05)$.

\section{Sagebrush Characteristics}

Sagebrush density and cover was greater in the seedling compared to seeded plots (Fig. $3 \mathrm{~A}$ and $3 \mathrm{~B} ; P<0.01$ and $=0.04$ ). In 2012, sagebrush density and cover was 13.6and 21-fold higher in the seedling compared to seeded plots. Sagebrush density also varied by control level and year (Fig. $3 \mathrm{~A} ; P<0.01$, and 0.02 , respectively). The highest control level

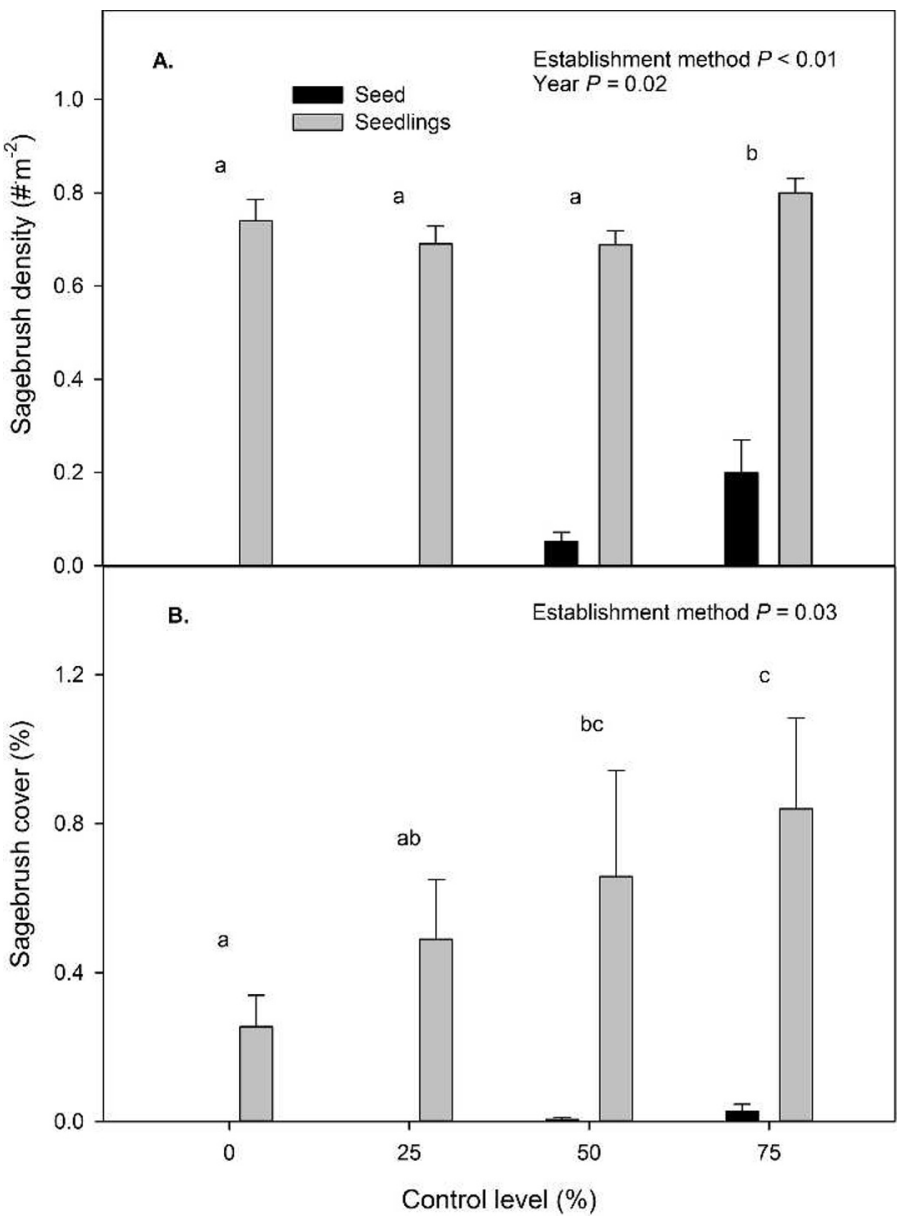

Figure 3. Sagebrush cover (A) and density (B) in plots where sagebrush was planted as seedlings or broadcast seeded in crested wheatgrass stands with varying rates of crested wheatgrass control with glyphosate. Sagebrush density was averaged over the $3 \mathrm{yr}$ of the study and sagebrush cover is from the third year posttreatment. Different lower case letters indicate differences $(P \leq 0.05)$ in response variable between control levels applied to crested wheatgrass.

had the greatest sagebrush density $(P<0.05)$, but the other control levels did not vary in sagebrush density $(P>0.05)$. Seeded sagebrush established only at the highest rates of crested wheatgrass control. Sagebrush density slightly decreased over time $(P=0.02)$. In 2010 , sagebrush density was $0.81 \pm 0.03$ and $0.07 \pm 0.03$ plants $\cdot \mathrm{m}^{-2}$ in the seedling and seeded plots, respectively. In 2012, density had decreased to $0.68 \pm 0.03$ and $0.05 \pm 0.03$ plants $\cdot \mathrm{m}^{-2}$ in the seedling and seeded plots, respectively. Interactions between control level and establishment method and between year and control level or establishment method did not significant influence sagebrush density $(P>0.05)$. Sagebrush cover generally increased with higher control levels $(P=0.03)$. In the third year after planting, sagebrush cover was threefold greater in the $75 \%$ control compared to the $0 \%$ control level plots. In the seedling plots, sagebrush height and canopy area was generally greater at higher control levels ( $P<0.01$ and 0.04 , respectively). In 2012, sagebrush height was 1.4 -fold $(\sim 6 \mathrm{~cm})$ greater in the $50 \%$ and $75 \%$ control level plots than the $0 \%$ control plots (Fig. 4A; $P=0.04$ and 0.04 , respectively). Sagebrush height did not vary among the other control levels $(P>0.05)$. In the seedling plots, 


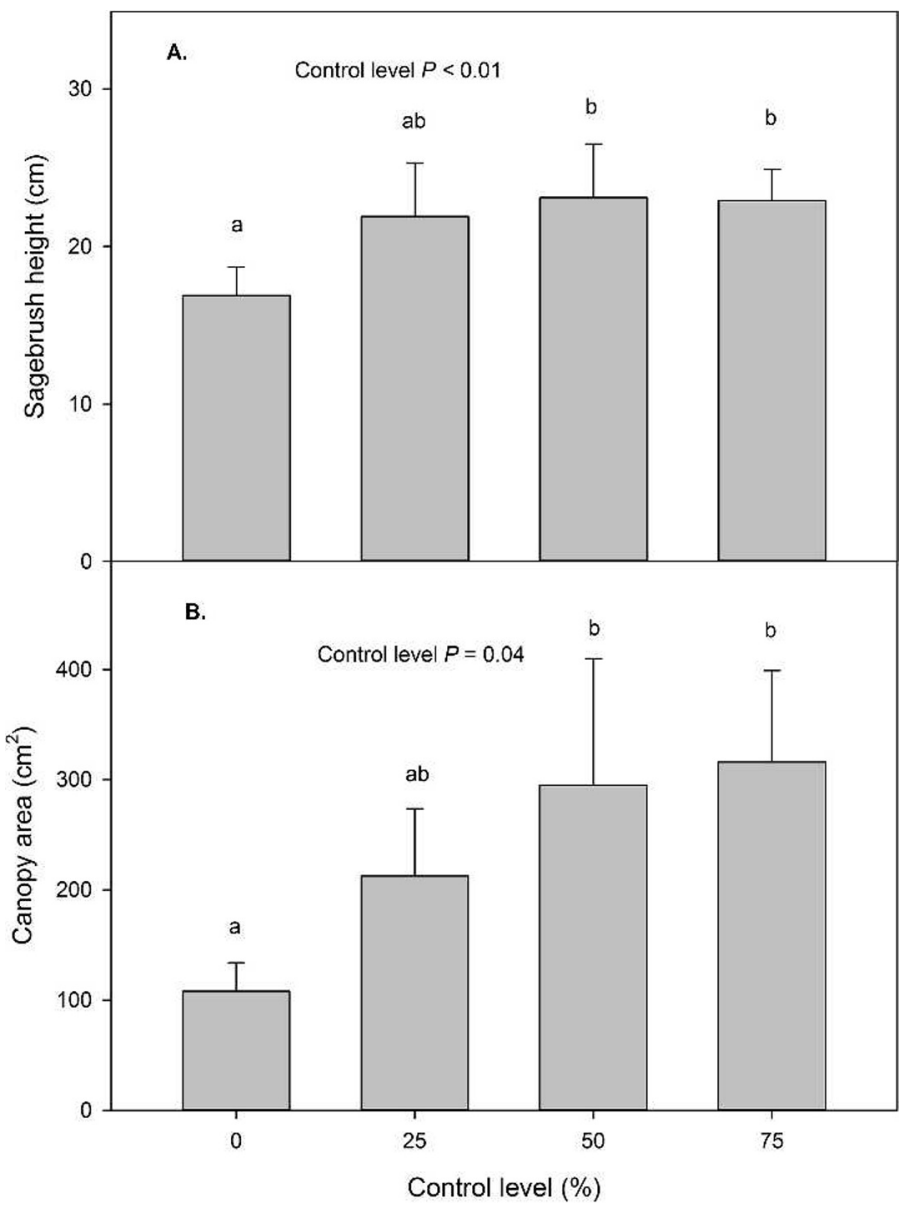

Figure 4. Height (A) and canopy area (B) of sagebrush planted as seedlings $3 \mathrm{yr}$ prior in crested wheatgrass stands with varying levels of crested wheatgrass control with glyphosate. Different lower case letters indicate response variable differences $(P \leq 0.05)$ between control levels.

sagebrush canopy area was $2.7-$ and 2.9 -fold greater in the $50 \%$ and $75 \%$ control level plots compared to $0 \%$ control plots $3 \mathrm{yr}$ after planting (Fig. 4B; $P=0.04$ and 0.02, respectively). Canopy area was not different among the other control levels $(P>0.05)$.

\section{DISCUSSION}

Wyoming big sagebrush establishment was greater using seedlings than seeds. Sagebrush did not establish from seeds where crested wheatgrass was not controlled or at the lowest control level. In contrast, planted seedling survival was about $70 \%$, even without control of crested wheatgrass. Therefore, it was not critical in our study to control crested wheatgrass for planted sagebrush seedlings to persist, which is probably due to some niche differentiation between sagebrush and crested wheatgrass as sagebrush matures (Gunnell et al. 2010). However, sagebrush plants were larger and sagebrush cover was greater $3 \mathrm{yr}$ posttreatment at the higher levels of crested wheatgrass control, probably due to an increase in resources for their growth. This indicates that competition between sagebrush and crested wheatgrass for limited resources may pronouncedly affect their early growth (Cook and Lewis 1963).
Our study also occurred during average to above-average precipitation years; crested wheatgrass control may have had a more evident effect on sagebrush persistence and growth in drier years.

Our results suggest that Wyoming big sagebrush, at times, can be established from seeds when crested wheatgrass is controlled, though the density was 34.5- and 4.2-fold less than seedling planted plots at the $50 \%$ and $75 \%$ control level, respectively. Efforts to establish shrubs, especially Wyoming big sagebrush, in rangelands from seed often have low success rates. In Oregon, Fansler and Mangold (2011) reported that few seeded shrubs emerged when crested wheatgrass was controlled. Lysne and Pellant (2004) reported that 23 out of 35 Wyoming big sagebrush seeding projects in Idaho failed and that density of sagebrush on seeded compared to nonseeded plots was not significantly different. The low density of Wyoming big sagebrush in the seeded plots, even with high control of crested wheatgrass, implies that additional recruitment events will need to occur before the community will be converted to a sagebrush-crested wheatgrass community. In southeast Oregon, Davies and Bates (2010) reported that average density of mature sagebrush plants in relatively intact Wyoming big sagebrush plant communities was 0.5 individuals $\cdot \mathrm{m}^{-2}$. Sagebrush density in the broadcast seeded plots at the $50 \%$ and $75 \%$ crested wheatgrass control levels need to increase 25.0- and 2.6-fold to achieve this density, respectively. Effective control of crested wheatgrass creates opportunities for establishing sagebrush from seed, but densities in our study were substantially less than sagebrush densities in intact communities and will probably take many years to increase to these levels.

Crested wheatgrass cover and density were significantly reduced with the highest levels of control. However, crested wheatgrass appears to rapidly recruit new individuals from seed into the community after disturbance, making it difficult to control with a single entry approach. By the third year postcontrol, mature crested wheatgrass density was similar between the $0 \%$ and $75 \%$ control plots as new individuals were recruited into the community. Similar to our results, others have found that crested wheatgrass control is short lived (Bakker et al. 1997; Cox and Anderson 2004; Hulet et al. 2010; Fansler and Mangold 2011). Our results support ascertains that effective control of crested wheatgrass would require multiple control applications to effectively reduce crested wheatgrass and its seed bank (Hulet et al. 2010; Fansler and Mangold 2011).

We measured an increase in annual forb cover, largely the exotic species desert matwort, and exotic annual grass density with high levels of crested wheatgrass control, suggesting that effective control of crested wheatgrass may increase the risk that the plant community will convert to an exotic annualdominated community. Similarly, Hulet et al. (2010) reported that exotic annuals pose a significant threat if crested wheatgrass is successfully controlled. The exotic annuals were probably able to capitalize on the increase in resources with higher crested wheatgrass control levels. Exotic annuals have repeatedly demonstrated an ability to increase after disturbances in sagebrush steppe ecosystems (Chambers et al. 2007; Boyd and Svejcar 2011; Davies et al. 2012). In low to midelevation sagebrush plant communities, treatments that suc- 
cessfully control crested wheatgrass for multiple years but fail to establish perennial-dominated plant communities to occupy the open niches will probably be converted to exotic annual grasslands. Given that most efforts to establish native plant species in Wyoming big sagebrush plant communities fail (Eiswerth et al. 2009), diversification projects in crested wheatgrass stands using native herbaceous species may largely increase the risk of conversion to exotic annual grasslands.

The general lack of a response from native perennial herbaceous vegetation to varying levels of crested wheatgrass control is not surprising. Native perennial herbaceous vegetation was lacking or severely limited across all treatment plots. For example, there was less than one large native perennial bunchgrass per $10 \mathrm{~m}^{2}$. Thus, the seed bank for native perennial vegetation was probably limited. Crested wheatgrass often dominates the seedbank after it is established (Marlette and Anderson 1986; Henderson and Naeth 2005). In addition, natural recruitment of native perennial herbaceous vegetation is often limited or lacking in Wyoming big sagebrush communities after disturbance (Davies et al. 2007; Davies et al. 2011a; Davies et al. 2012), probably due to episodic recruitment events and competition from exotic annuals. Even when native perennial herbaceous species were seeded after crested wheatgrass control, they largely have failed to establish (Hulet et al. 2010; Fansler and Mangold 2011). They may initially emerge, but survival is low due to harsh environmental conditions and competition with crested wheatgrass (Gunnell et al. 2010; Fansler and Mangold 2011).

Establishing foundation species, such as sagebrush, may be more successful than trying to reestablish the full assemblage of native plant species in crested wheatgrass stands. Our results suggest that sagebrush can be established in crested wheatgrass stands without applying control treatments. This decreases the cost, though planting seedlings is expensive, and reduces the risk of exotic annuals dominating the plant community. Reestablishing sagebrush by planting seedlings will accelerate recovery of key habitat elements for sage-grouse and other sagebrush-associated wildlife. Three years posttreatment sagebrush density in the seedling plots was greater than the average reported for relatively intact Wyoming big sagebrush communities (Davies and Bates 2010); however, sagebrush cover was still low. We found that control of crested wheatgrass increased sagebrush plant size and cover; thereby, treatments that alter the competitive relationship between crested wheatgrass and sagebrush may potentially increase the recovery of sagebrush cover. For example, grazing crested wheatgrass may be a passive and inexpensive treatment to favor accelerated growth of sagebrush plants. Though evaluating native rangeland, Laycock (1967) found that heavy spring grazing increased sagebrush by decreasing herbaceous production. Additional research is needed to determine how long it takes for recovery of sagebrush cover and whether inexpensive treatments could accelerate that recovery.

\section{MANAGEMENT IMPLICATIONS}

The results of our study demonstrated that planting seedlings is more successful at establishing sagebrush in crested wheatgrass stands than broadcast seeding. Planted seedlings established and persisted at high rates even without controlling crested wheatgrass. However, high levels of crested wheatgrass control did increase the growth of planted sagebrush seedlings and allowed some success with broadcast seeded sagebrush. In years drier than those during our study, control of crested wheatgrass may be needed to improve establishment of planted sagebrush seedlings. Planting seedlings may not have been successful if higher populations of sagebrush consumers (e.g., jackrabbits, mule deer, etc.) had occurred in the study area. The rapid recovery of crested wheatgrass following control treatments implies that multiple control applications may be required to reduce crested wheatgrass dominance. Control of crested wheatgrass, however, increased exotic annuals, suggesting that successful control of crested wheatgrass for multiple years would pose a significant risk of converting the plant community to an exotic annual rangeland. Our results suggest that natural recovery of native perennial herbaceous vegetation, even with control of crested wheatgrass, is unlikely, probably due to a depleted seed bank and limited recruitment. Our results also suggest that it is possible to diversify the composition and structure of crested wheatgrass stands by planting Wyoming big sagebrush seedlings even without applying treatments to control crested wheatgrass. Further evaluation will be needed to determine when sagebrush cover has increased to the point of providing good quality habitat for sagebrush-associated wildlife. We hypothesize that patches or strips of Wyoming big sagebrush seedlings could be established across crested wheatgrass seedings and other areas in need of sagebrush restoration to facilitate sagebrush recovery in areas too large, due to finite resources, to plant seedlings across their entirety. When the seedlings mature, they would provide a seed source across the area to capitalize on climatic conditions that favor sagebrush recruitment. This could provide an opportunity to accelerate the recovery of Wyoming big sagebrush and sagebrush-associated wildlife habitat across large areas.

\section{ACKNOWLEDGMENTS}

The authors thank the Malheur National Wildlife Refuge for allowing this research to be conducted on lands they administer. We especially appreciated logistical assistance provided by Jess Wenick. Assistance with data collection by Brandi Carlon, Sarah Fitzpatrick, Julie Garner, Savannah Duff, Rodney Johnson, Tim Rowe, Anne Crecelius, and Alanna Riggs was greatly appreciated. We also are grateful to Dustin Johnson and Matt Madsen for reviewing earlier versions of this manuscript. We also appreciate the thoughtful reviews by the anonymous reviewers and associate editor.

\section{LITERATURE CITED}

Arredondo, J. T., T. A. Jones, and D. A. Johnson. 1998. Seedling growth of Intermountain perennial and weedy annual grasses. Journal of Range Management 51:584-589.

Asay, K. H., W. H. Horton, K. B. Jensen, and A. J. Palazzo. 2001. Merits of native and introduced Triticeae grasses on semiarid rangelands. Canadian Journal of Plant Science 81:45-52.

Bakker, J. D., J. Christian, S. D. Wilson, and J. Waddington. 1997. Seeding blue grama in old crested wheatgrass fields in southwestern Saskatchewan. Journal of Range Management 50:156-159. 
Boyd, C. S., And K. W. Davies. 2010. Shrub microsite influences post-fire perennial grass establishment. Rangeland Ecology \& Management 63:248-252.

BoYd, C. S., AND K. W. Davies. 2012. Spatial variability in cost and success of revegetation in a Wyoming big sagebrush community. Environmental Management 50:441-450.

Boyd, C. S., AND T. J. SvejCar. 2011. The influence of plant removal on succession in Wyoming big sagebrush. Journal of Arid Environments 75:734-741.

Chambers, J. C., R. A. Roundy, R. R. Blank, S. E. Meyer, and A. Whittaker. 2007. What makes Great Basin sagebrush ecosystems invasible by Bromus tectorum? Ecological Monographs 77:117-145.

Cook, C. W., AND C. E. LewIs. 1963. Competition between sagebrush and seeded grasses on foothill ranges in Utah. Journal of Range Management 16:245-250.

Cox, R. D., and V. J. Anderson. 2004. Increasing native diversity of cheatgrassdominated rangeland through assisted succession. Journal of Range Management 57:203-210.

Davies, K. W., AND J. D. Bates. 2010. Vegetation characteristics of mountain and Wyoming big sagebrush plant communities in the northern Great Basin. Rangeland Ecology \& Management 63:461-466.

Davies, K. W., J. D. Bates, and R. F. Miller. 2007. Short-term effects of burning Wyoming big sagebrush steppe in southeast Oregon. Rangeland Ecology \& Management 60:515-522.

Davies, K. W., J. D. Bates, and A. M. Nafus. 2011a. Are there benefits to mowing intact Wyoming big sagebrush communities? An evaluation in southeastern Oregon. Environmental Management 48:539-546.

Davies, K. W., J. D. Bates, and A. M. Nafus. 2012. Mowing Wyoming big sagebrush communities with degraded herbaceous understories: has a threshold been crossed? Rangeland Ecology \& Management 65:498-505.

Davies, K. W., C. S. Boyd, J. L. Beck, J. D. Bates, T. J. Svejcar, and M. A. Gregg. 2011b. Saving the sagebrush sea: an ecosystem conservation plan for big sagebrush plant communities. Biological Conservation 144:2573-2584.

Davies, K. W., A. M. Nafus, and R. L. Sheley. 2010. Non-native competitive perennial grass impedes the spread of an invasive annual grass. Biological Invasions 12:3187-3194.

Eiswerth, M. E., K. Krauter, S. R. Swanson, and M. Zielinski. 2009. Post-fire seeding on Wyoming big sagebrush ecological sites: regression analyses of seeded nonnative and native species densities. Journal of Environmental Management 90:1320-1325.

Epanchin-Niell, R., J. Englin, and D. Nalle. 2009. Investing in rangeland restoration in the arid west, USA: countering the effects of an invasive weed on the long-term fire cycle. Journal of Environmental Management 91:370-379.

Fansler, V. A., and J. M. Mangold. 2011. Restoring native plants to crested wheatgrass stands. Restoration Ecology 19:16-23.

FrISCHKNECHT, N. C. 1968. Factors influencing halogeton invasion of crested wheatgrass range. Journal of Range Management 21:8-12.

Gunnell, K. T., T. A. Monaco, C. A. Call, and C. V. Ransom. 2010. Seedling interference and niche differentiation between crested wheatgrass and contrasting native great basin species. Rangeland Ecology \& Management 63:443-449.

Hansen, M. J., AND S. D. WiLSON. 2006. Is management of an invasive grass Agropyron cristatum contingent on environmental variation? Journal of Applied Ecology 43:269-280.

Henderson, D. C., and M. A. Naeth. 2005. Multi-scale impacts of crested wheatgrass invasion in mixed-grass prairie. Biological Invasions 7:639-650.

Hulet, A., B. A. Roundy, AND B. Jessop. 2010. Crested wheatgrass control and native plant establishment in Utah. Rangeland Ecology \& Management 63:450-460.

HuLL, A. C. 1974. Species for seeding arid rangeland in southern Idaho. Journal of Range Management 27:216-218.
HuLL, A. C., AND G. J. KLomp. 1967. Thickening and spread of crested wheatgrass stands on southern Idaho ranges. Journal of Range Management 20:222-227.

Kennedy, P. L., S. J. DeBano, A. M. Bartuszevige, and A. S. Lueders. 2009. Effects of native and non-native grassland plant communities on breeding passerine birds: implications for restoration of northwest bunchgrass prairie. Restoration Ecology 17:515-525.

Knick, S. T., D. S. Dobkin, J. T. RotenberRy, M. A. Schroeder, W. M. Vander Haegen, and C. V. RIPER. 2003. Teetering on the edge or too late? Conservation and research issues for avifauna of sagebrush habitats. Condor 105:611-634.

LaYcock, W.A. 1967. How heavy grazing and protection affect sagebrush-grass ranges. Journal of Range Management 20:206-213.

Lesica, P., And T. H. Deluca. 1996. Long-term harmful effects of crested wheatgrass on Great Plains grassland ecosystems. Journal of Soil and Water Conservation $51: 408-409$.

Littell, R. C., G. A. Milliken, W. W. Stroup, and R. D. Wolfinger. 1996. SAS system for mixed models [computer program]. Cary, NC, USA: SAS Institute. 633 p.

Lysne, C. R., AND M. L. PelLant. 2004. Establishment of aerially seeded big sagebrush following southerm Idaho wildfires. Boise, ID, USA: USDA and Department of the Interior, Bureau of Land Management. Technical Bulletin 2004-01. 14 p.

Marlette, G. M., and J. E. Anderson. 1986. Seed banks and propagule dispersal in crested-wheatgrass stands. Journal of Applied Ecology 23:161-175.

Maryland, H. F., K. H. Asay, and D. H. Clark. 1992. Seasonal trends in herbage yield and quality of Agropyrons. Journal of Range Management 45:369-374.

McAdoo, J. K., W. S. Longland, and R. A. Evans. 1989. Nongame bird community responses to sagebrush invasion of crested wheatgrass seedings. Journal of Wildlife Management 53:494-502.

MlıleR, R. K. 1956. Control of halogeton in Nevada by range seedings and herbicides. Journal of Range Management 9:227-229.

Pellant, M., And C. R. Lysne. 2005. Strategies to enhance plant structure and diversity in crested wheatgrass seedings. In: N. L. Shaw, M. Pellant, and S. B. Monsen [comps.]. Proceedings: sage-grouse habitat restoration symposium proceedings; 4-7 June 2001; Boise, ID, USA. Fort Collins, C0, USA: USDA Forest Service. RMRS-P-38. p. 81-92.

Prevéy, J. S., M. J. Germino, N. J. Huntly, and R. S. Inouye. 2010. Exotic plants increase and native plants decrease with loss of foundation species in sagebrush steppe. Plant Ecology 207:39-51.

Robertson, J. H., R. E. ECKert, And A. T. BleAk. 1966. Response of grasses seeded in Artemisia tridentata habitat in Nevada. Ecology 47:187-194.

Romo, J. T. 2005. Emergence and establishment of Agropyron desertorum (Fisch.) (crested wheatgrass) seedlings in a Sandhills prairie of central Saskatchewan. Natural Areas Journal 25:26-35.

Schroeder, M. A., C. L. Aldridge, A. D. Apa, J. R. Bohne, C. E. Braun, S. D. Bunnell, J. W. Connelly, P. A. Deibert, S. C. Gardner, M. A. Hilliard, G. D. Kobriger, S. M. McAdam, C. W. McCarthy, J. J. McCarthy, D. L. Mitchell, E. V. Rickerson, and S. J. Stiver. 2004. Distribution of sage-grouse in North America. Condor 106:363-376.

VAneSS, B. M., AND S. D. WILSON. 2008. Impacts and management of crested wheatgrass (Agropyron cristatum) in the northern Great Plains. Canadian Journal of Plant Science 87:1023-1028.

Waldron, B. L., T. A. Monaco, K. B. Jensen, R. D. Harrison, A. J. Palazzo, and J. D. KuLBETH. 2005. Coexistence of native and introduced perennial grasses following simultaneous seeding. Agronomy Journal 97:990-996.

Western Regional Climate Center. 2012. Cooperative climatological data summaries. Available at: http://www.wrcc.dri.edu/climatedata/climsum/. Accessed 2 October 2012. 